\title{
PROFIL PERALATAN DAN KETERLAKSANAAN PRAKTIKUM FISIKA SMA DI WILAYAH MISKIN PROPINSI BENGKULU
}

\author{
Desy Hanisa Putri, Sutarno dan Eko Risdianto \\ Program Studi Pendidikan Fisika, Jurusan Pendidikan MIPA \\ Fakultas Keguruan dan Ilmu Pendidikan Universitas Bengkulu \\ Jalan Raya Kandang Limun Bengkulu \\ Email : desyhanisaputri@gmail.com
}

\begin{abstract}
ABSTRAK
Penelitian ini bertujuan memperoleh gambaran peralatan dan keterlaksanaan praktikum fisika, dan hambatanhambatan yang dialami guru dalam menyelenggarakan praktikum fisika di sekolah-sekolah SMA di wilayah miskin Provinsi Bengkulu. Subyek penelitian adalah guru fisika dan laboratorium fisika di 20 sekolah SMA Negeri yang tersebar dalam 10 Kabupaten/Kota di wilay ah miskin Propinsi Bengkulu yang dipilih dengan teknik purposive sampling. Penelitian dilakukan dengan metode deskriptif dan observasi dengan instrumen berupa angket dan lembar observasi. Berdasarkan hasil analisis data diperoleh bahwa :1) Peralatan praktikum fisika yang terdapat di sekolah SMA di wilayah miskin Propinsi Bengkulu adalah berupa KIT, alat ukur dasar, dan alat peraga fisika dengan ketersediaan yang minim dan kondisi kurang baik; 2) Jumlah keterlaksanaan praktikum fisika SMA di wilayah miskin Propinsi Bengkulu berada pada kategori kurang baik. 3) Hambatan-hambatan utama yang dialami guru dalam menyelenggarakan praktikum adalah berupa ketersediaan peralatan laboratorium yang terbatas, peralatan yang ada sudah banyak yang rusak, jam mengajar guru yang padat, dan praktikum membutuhkan waktu lama.
\end{abstract}

Kata Kunci : peralatan praktikum fisika, keterlaksanaan praktikum fisika, hambatan praktikum fisika

\begin{abstract}
This study aims to obtain a physics experiment equipment and feasibility and obstacles in conducting experiment physics at high schools in poor areas of Bengkulu Province. Subjects were physics teachers and physics laboratories in 20 schools spread state high schools in 10 districts in poor areas of Bengkulu Province selected by purposive sampling technique. The study was conducted with descriptive methods and observations with instruments such as questionnaires and observation sheets. Based on the analysis of data obtained that : 1 ) the physics experiment equipments contained in the high school in a poor area of Bengkulu Province are a KIT, basic measuring tools, and the availability of phy sical props are minimal and unfavorable conditions. 2) The number of high school physics experiment in poor areas are in unfavorable category. 3) The main constraints experienced by teachers in the physics experiment is held in the form of a limited availability of laboratory equipment, there are already many tools that are damaged, congested teachers teaching hours, and physics experiment takes a long time.
\end{abstract}

Keywords : physics experiment equipment, experiment enforceability of physics, physics experiment obstacle

\section{PENDAHULUAN}

Salah satu upaya pemerintah dalam mewujudkan pendidikan bermutu adalah melalui dorongan pelaksanaan pembelajaran sains berorientasi pada aspek proses, produk, dan sikap. Namun, jika dicermati, pembelajaran sains di Indonesia khususnya fisika cenderung hanya menekankan pada aspek produk saja, dimana fakta, hukum dan teori mendapat porsi yang dominan, sedangkan aspek proses dan sikap kurang mendapat perhatian. Hal ini disebabkan antara lain oleh kurang maksimalnya pelaksanaan praktikum akibat minimnya daya dukung prasarana laboratorium sains yang dimiliki sekolah (Setiawan, 2009).

Berdasarkan hasil observasi mahasiswa program studi Pendidikan Fisika Universitas Bengkulu (Unib) yang melaksanakan kegiatan praktek pengalaman lapangan (PPL) tahun 2011 di sekolah-sekolah di wilayah kota Bengkulu, didapatkan gambaran bahwa intensitas kegiatan praktikum untuk mata pelajaran fisika umumnya masih rendah. Pelaksanaan pembelajaran fisika belum didukung oleh kegiatan percobaan di laboratorium. Alasan yang dikemukakan guru diantaranya adalah minimnya ketersediaan peralatan praktikum, banyak peralatan yang sudah rusak, dan sistem pengelolaan laboratorium yang kurang baik 
sehingga menghambat kegiatan praktikum. Selain hal itu, guru berpendapat bahwa kegiatan praktikum banyak menghabiskan waktu.

Jika keadaan pembelajaran fisika di sekolahsekolah SMA di wilayah kota Bengkulu saja umumnya belum didukung oleh keterlaksanaan praktikum fisika akibat minimnya peralatan praktikum, maka memungkinkan bahwa keterlaksanaan praktikum di sekolah-sekolah SMA di wilayah yang jauh dari kota Bengkulu bisa lebih memprihatinkan. Sekolah-sekolah yang jauh dari wilayah kota Bengkulu memungkinkan memiliki hambatan yang lebih kompleks dalam menyelenggarakan praktikum. Hal ini dapat dipahami karena sebagian besar wilayah yang jauh dari kota Bengkulu merupakan wilayah pemekaran kabupaten baru yang masih tergolong miskin.

Aspek proses yang ingin dikembangkan pada pembelajaran sains adalah keterampilan proses sains melalui kegiatan laboratorium. Keterampilan proses sains diperlukan untuk melatih keterampilan berpikir tingkat tinggi berupa keterampilan berpikir kreatif, kritis, dan pemecahan masalah (Putri, 2012). Minimnya prasarana laboratorium sains yang dimiliki sekolah dapat menghambat pengembangan keterampilan proses sains siswa (Manurung dan Rustaman, 2010).

Pada laporan pemerintah tentang Pencapaian Millenium Development Goals (MDGs), provinsi Bengkulu masuk 10 besar dari 33 provinsi di seluruh Indonesia yang berada pada status dan kondisi kemiskinan tahun 2006. Persentase penduduk miskinnya pada tahun 2006 mencapai $20,90 \%$, sementara angka rata-rata kemiskinan nasional sebesar 16,56\% (MDGs, 2007). Lebih lanjut, berdasarkan laporan Badan Pusat Statistik Provinsi Bengkulu, penduduk miskin di provinsi Bengkulu pada Tahun 2010 sebesar 18,30\% dari total jumlah penduduk sebanyak 1,5 juta jiwa (Carsadi, 2011). Jumlah siswa miskin di provinsi Bengkulu Tahun 2010 tercatat sebesar 25.040 orang dan $15,56 \%$ diantaranya merupakan siswa SMA (Antara News, 2010). Lebih lanjut dipaparkan, kemiskinan di provinsi Bengkulu terdapat di hampir seluruh wilayah.

Informasi akurat tentang pofil peralatan dan keterlaksanaan praktikum, serta hambatanhambatan yang dialami guru fisika dalam menyelenggarakan praktikum di sekolah-sekolah SMA di wilayah miskin provinsi Bengkulu sangat dibutuhkan. Hal ini diperlukan sebagai dasar pertimbangan bagi perbaikan proses pembelajaran fisika yang harus tetap mengakomodasi kegiatan praktikum.

\section{METODE PENELITIAN}

Penelitian yang dilakukan merupakan penelitian deskriptif. Subjek penelitian ini adalah guru fisika, dan laboratorium fisika dari 20 sekolah SMA Negeri yang tersebar di 10 kabupaten/kota di wilayah miskin di provinsi Bengkulu yang dipilih secara purposif. Instrumen penelitian yang digunakan adalah angket dan pedoman observasi. Angket digunakan untuk memperoleh data gambaran prasarana laboratorium, keterlaksanaan praktikum, dan gambaran hambatan-hambatan yang dialami guru fisika dalam menyelenggarakan praktikum. Lembar observasi digunakan sebagai pedoman pada saat melakukan observasi laboratorium sekolah.

\section{HASIL DAN PEMBAHASAN}

\section{Ketersediaan Pealatan Praktikum}

Peralatan praktikum yang dimaksud adalah peralatan penunjang praktikum berbentuk kit fisika dan peralatan praktikum selain kit. Data gambaran peralatan praktikum diperoleh berdasarkan data angket yang disebarkan pada guru fisika dan kegiatan observasi laboratorium.

Berdasarkan data angket ditemukan 6 jenis kit fisika yang terdapat di sekolah-sekolah SMA di wilayah miskin provinsi Bengkulu yaitu kit Listrik dan Magnet, Hidrostatika dan Panas, Gelombang Optik, Mekanika, dan kit Termodinamika dengan jumlah total sebanyak 181 unit. Namun demikian sebanyak 65,2\% dari jumlah kit tersebut sudah dalam keadaan tidak lengkap. Selain kit, terdapat beberapa peralatan penunjang praktikum yang tersedia yaitu voltmeter, amperemeter, power supply, audio generator, tabung Bernoulli, termometer, stopwatch, garpu tala, osiloskop, slinki, tangki riak, photometer, jembatan Wheatstone, avometer, galvanometer, sonometer, alat peraga panahan, mobil bergerak, roket air dan bandul sederhana. Peralatan tersebut umunya tergolong sebagai alat ukur dasar dan alat peraga fisika yang ketersediaannya dalam bentuk satuan-satuan yang terpisah, tidak membentuk suatu unit peralatan yang siap digunakan untuk melakukan praktikum tertentu. Peralatan yang ada hanya berupa peralatan pendukung praktikum tertentu dengan jumlah ketersediaan yang minim.

\section{Gambaran Keterlaksanaan dan Hambatan Praktikum Fisika}

Terdapat 31 judul praktikum yang direncanakan pada kurikulum sekolah-sekolah SMA di wilayah miskin provinsi Bengkulu. Distribusi juduljudul praktikum tersebut yaitu 10 judul praktikum untuk kelas X, 9 judul praktikum untuk kelas XI, dan 11 judul praktikum untuk kelas XII. Hasil analisis data angket menunjukkan bahwa juduljudul praktikum yang direncanakan tersebut belum dapat dilaksanakan secara maksimal (Tabel 1). 
Tabel 1. Keterlaksanaan praktikum

\begin{tabular}{|c|c|c|c|c|}
\hline Kelas & & Judul Praktikum & & Persentase $(\%)$ \\
\hline \multirow[t]{12}{*}{$\bar{X}$} & 1 & Pengukuran & & 85 \\
\hline & 2 & Gerak Lurus & & 35 \\
\hline & 3 & Gerak Melingkar & & 15 \\
\hline & 4 & Hukum Newton: Gaya Gesek & & 30 \\
\hline & 5 & Alat-Alat Optik & & 45 \\
\hline & 6 & Optik Geometri & & 10 \\
\hline & 7 & Kalorimeter & & 30 \\
\hline & 8 & Hukum Ohm & & 45 \\
\hline & 9 & Pengukuran Arus -Tegangan & & 5 \\
\hline & 10 & Rangkaian Listrik Seri-Paralel & & 15 \\
\hline & & & Rerata kelas X (\%) & 31,5 \\
\hline & & & Kategori & Cukup Baik \\
\hline \multirow[t]{10}{*}{ XI } & 1 & Bandul Sederhana & & 75 \\
\hline & 2 & Hukum Hook (elastisitas pegas) & & 55 \\
\hline & 3 & Usaha dan Energi & & 10 \\
\hline & 4 & Tumbukan & & 15 \\
\hline & 5 & Massa Jenis & & 15 \\
\hline & 6 & Fluida (Gay a Hidrostatik) & & 5 \\
\hline & 7 & Hukum Archimedes & & 25 \\
\hline & 8 & Titik Berat & & 35 \\
\hline & 9 & Termodinamika & & 5 \\
\hline & & & $\begin{array}{l}\text { Rerata kelas XI (\%) } \\
\text { Kategori }\end{array}$ & $\begin{array}{l}26,7 \\
\text { Cukup Baik }\end{array}$ \\
\hline \multirow[t]{14}{*}{ XII } & 1 & Pemantulan-Pembiasan Cahaya & & 60 \\
\hline & 2 & Hukum Melde & & 5 \\
\hline & 3 & Gelombang pada Tali & & 0 \\
\hline & 4 & Perambatan Gelombang & & 45 \\
\hline & 5 & Listrik Statis : Kapasitor & & 5 \\
\hline & 6 & Hukum Faraday & & 0 \\
\hline & 7 & Rangkaian RLC & & 0 \\
\hline & 8 & Medan Magnet & & 20 \\
\hline & 9 & Gay a Lorentz & & 5 \\
\hline & 10 & Arus ac : Hukum Kirchoff & & 0 \\
\hline & 11 & Transformator & & 5 \\
\hline & 12 & Induksi Elektromagnet & & 0 \\
\hline & & & $\begin{array}{l}\text { Rerata kelas XII (\%) } \\
\text { Kategori }\end{array}$ & $\begin{array}{c}12,1 \\
\text { Kurang Baik }\end{array}$ \\
\hline & & $\begin{array}{l}\text { Rerata } \text { Total }=23,4 \% \\
\text { Kategori Total = Kurang Baik }\end{array}$ & & \\
\hline
\end{tabular}

Tabel 2. Hambatan dalam penyelenggaraaan praktikum fisika

\begin{tabular}{lcc}
\hline \multicolumn{1}{c}{ Bentuk Hambatan } & \multicolumn{2}{c}{ Jumlah Sekolah } \\
\cline { 2 - 3 } & Ya & Tidak \\
\hline Ketersediaan prasarana laboratorium dan alat praktikum yang terbatas & 16 & 4 \\
Peralatan y ang ada bany ak y ang telah rusak & 15 & 5 \\
Jam mengajar guru padat & 15 & 5 \\
Praktikum membutuhkan waktu lama & 12 & 8 \\
Pengelolaan laboratorium belum baik/maksimal & 6 & 14 \\
Tidak ada laboran yang membantu menyiapkan alat & 13 & 7 \\
Tidak ada Lembar Kerja Siswa/penuntun praktikum & 7 & 13 \\
Guru mengalami kesulitan dalam merancang praktikum & 4 & 16 \\
Motivasi siswa dalam praktikum rendah & 4 & 16 \\
\hline \multicolumn{1}{c}{ Total } & $\mathbf{9 2}$ & $\mathbf{8 8}$ \\
\hline
\end{tabular}


Untuk kelas $\mathrm{X}$, judul praktikum fisika yang paling banyak dilakukan oleh sekolah adalah praktikum pengukuran, pengenalan alat-alat optik dan hukum Ohm, sedangkan judul-judul yang lain keterlaksanaannya masih sangat rendah. Keterlaksanaan praktikum kelas $\mathrm{X}$ berada pada kategori cukup baik.

Pada kelas XI, judul praktikum fisika yang paling banyak dilakukan adalah bandul sederhana, hukum Hooke dan penentuan titik berat. Juduljudul yang lain keterlaksanaannya masih sangat rendah. Keterlaksanaan praktikum kelas XI untuk sekolah responden berada pada kategori cukup baik. Pada kelas XII, judul praktikum fisika yang paling banyak dilakukan adalah praktikum pembiasan cahaya dan perambatan gelombang. Juduljudul praktikum yang lain keterlaksanaannya masih sangat rendah. Bahkan terdapat 5 judul praktikum yang tidak dilakukan yaitu praktikum gelombang pada tali, hukum Faraday, rangkaian RLC, dan hukum Kirchoff. Keterlaksanaan praktikum kelas XII berada pada kategori kurang baik. Sedangkan keterlaksanaan semua judul praktikum yang meliputi seluruh jenjang kelas berada pada kategori kurang baik. Rendahnya keterlaksanaan praktikum fisika di sekolah-sekolah SMA di wilayah miskin propinsi Bengkulu diduga disebabkan oleh adanya hambatan-hambatan yang dihadapi guru dalam menyelenggarakan praktikum. Bentuk-bentuk hambatan yang dialami ditunjukkan pada Tabel 2 . Terdapat sebanyak $51,1 \%$ sekolah mengalami hambatan dalam menyelenggarakan praktikum. Terdapat enam bentuk hambatan yang dominan dialami sehingga praktikum tidak dapat dilakukan sesuai perencanaan. Hambatan-hambatan tersebut adalah: 1) ketersediaan prasarana/peralatan praktikum yang terbatas, 2) peralatan yang ada sudah banyak rusak, 3) jam mengajar guru yang padat, 4) tidak ada laboran yang membantu, 5) praktikum membutuhkan waktu yang lama, 6) tidak adanya penuntun praktikum (LKS).

\section{Pembahasan}

Berdasarkan hasil analisis data terlihat bahwa peralatan praktikum yang dimiliki oleh sekolah-sekolah SMA di wilayah miskin Provinsi Bengkulu umumnya berbentuk kit fisika. Namun demikian hanya sebanyak 34,8\% kit yang masih dalam keadaan lengkap. Sedangkan peralatan penunjang praktikum fisika lainnya yang ada adalah berupa alat ukur dasar dan alat peraga sederhana dengan jumlah ketersediaan minim.

Minimnya jumlah kit tersebut tentu dapat mengganggu keterlaksanaan praktikum di sekolah. Berdasarkan analisis keterlaksanaan praktikum, diketahui bahwa praktikum umumnya terlaksana adalah praktikum yang dapat dilakukan mengguna- kan kit fisika dan praktikum yang hanya membutuhkan peralatan sederhana. Beberapa praktikum yang umumnya terlaksana adalah praktikum pengukuran, pengenalan alat-alat optik, hukum Newton tentang gerak, hukum Ohm, pembiasan cahaya dan bandul fisis (pendulum sederhana). Keterlaksanaan judul-judul praktikum lainnya masih rendah, hal ini dikarenakan praktikum tersebut memerlukan peralatan praktikum khusus yang tidak dimiliki sekolah.

Ketersediaan peralatan praktikum yang terdapat di sekolah-sekolah SMA di wilayah miskin Propinsi Bengkulu pada umumnya merupakan bantuan dari peme-rintah. Namun demikian bantuan tersebut tidak dilakukan secara berkala dan periodik. Hanya terdapat $50 \%$ sekolah yang telah melakukan pengadaan peralatan laboratorium secara mandiri. Minimnya peralatan praktikum yang tersedia menyebabkan jumlah praktikum yang terlaksana masih berada pada kategori kurang baik. Persentase keterlaksanaan jumlah praktikum yang paling rendah didapati pada jenjang kelas XII. Pada jenjang ini, terdapat 5 judul praktikum yang sama sekali tidak terlaksana dari 12 praktikum yang direncanakan. Empat dari judul praktikum yang tak terlaksana tersebut merupakan praktikum pada konsep kelistrikan dan kemagnetan. Sedangkan judul praktikum yang paling sering dilakukan adalah praktikum pembiasan cahaya dan praktikum perambatan gelombang. Dua judul praktikum ini sering terlaksana karena peralatan yang diperlukan adalah berupa kit optik dan kit gelombang yang pada umumnya dimiliki sekolah.

Ketidaksesuaian antara jumlah keterlaksanaan praktikum di sekolah dengan jumlah judul praktikum yang direncanakan dalam kurikulum sekolah disebabkan oleh berbagai hambatan yang muncul. Terdapat 9 bentuk hambatan yang dialami guru dalam menyelenggarakan praktikum seperti ditunjukkan pada Gambar 1. Tiga bentuk hambatan yang dominan adalah ketersediaan peralatan praktikum yang minim, peralatan yang ada banyak yang sudah rusak, jam mengajar guru yang padat, dan tidak ada laboran yang membantu. Hambatan dengan persentase tertinggi yang dialami guru adalah minimnya ketersediaan peralatan praktikum. Ini merupakan bentuk hambatan yang umumnya terjadi pada kebanyakan sekolah SMA di Indonesia. Minimnya peralatan yang dimiliki sekolah selain disebabkan karena pemerintah tidak memberikan bantuan peralatan secara berkala dan periodik, juga karena sekolah tidak memiliki kemampuan pendanaan untuk melakukan pengadaan peralatan secara mandiri.

Terdapat beberapa rekomendasi yang diajukan untuk mengatasi permasalahan tersebut. Pertama, mengingat minimnya peralatan praktikum disekolah, guru diharapkan meningkatkan kreativitasnya dalam merancang peralatan praktikum 
dengan cara memanfaatkan barang dan alat sederhana yang terdapat di sekitar lingkungan sekolah atau tempat tinggal. Guru dapat melibatkan kreativitas siswa dalam merancang peralatan tersebut. Solusi ini memungkinkan untuk dilakukan mengingat banyak alat-alat sederhana disekitar kita yang dapat dijadikan sebagai media observasi, pengamatan, bahkan media praktikum sehingga kinerja ilmiah dan keterampilan proses sains siswa tetap dapat dilatihkan. Namun demikian terdapat tantangan utama yang muncul yaitu untuk melakukan semua itu dibutuhkan waktu dan perhatian yang cukup. Kenyataannya, waktu guru banyak dihabis kan untuk mencapai target materi pelajaran yang sangat luas. Selain itu, kegitan guru dalam menyiapkan berbagai perangkat pembelajaran juga telah menghabiskan sebagian besar waktu guru.

Kenyataan ini mengharuskan munculnya terobosan baru yang dapat dijadikan sebagai solusi alternatif bagi permasalahan tersebut. Solusi yang dihasilkan haruslah dapat membantu mengatasi ketidakterlaksanaan praktikum fisika, tidak bergantung pada ketersediaan peralatan praktikum fisika, dapat dilaksanakan lebih fleksibel, tidak membutuhkan banyak waktu sehingga tidak mengganggu jam mengajar guru yang padat, serta ekonomis dari segi pembiayaan. Solusi alternatif kedua yang dianggap memenuhi persayaratan tersebut adalah melalui praktikum virtual menggunakan simulasi komputer interaktif.

Terdapat beberapa kelebihan dan manfaat dalam praktikum virtual berbasis komputer, diantaranya adalah : praktikum virtual tetap dapat memungkinkan munculnya kegiatan minds-on dan hands-on sehingga dapat digunakan untuk melatih keterampilan proses sains siswa (Manurung dan Rustaman, 2010), praktikum virtual memudahkan siswa melakukan praktikum karena semua alat dan bahan telah disediakan secara virtual, membantu guru mengelola dan melaksanakan praktikum, memberikan pereduksian waktu pembelajaran, dan dapat mengembangkan potensi praktikum menjadi pembelajaran mandiri dan meningkatkan fleksibilitas dalam belajar (Hut, 2006). Berdasarkan hasil penelitian diperoleh hasil bahwa penggunaan simulasi interaktif sebagai alternatif praktikum fisika dapat meningkatkan penguasaan konsep bahasan rangkaian listrik dan dasar elektronika pada pada guru-guru fisika SMA di kota Manado (Wagania, 2008), dan penggunaan virtual eksperimen dapat mencegah miskonsepsi dalam pembelajaran sains (Sudibawa, 2010).

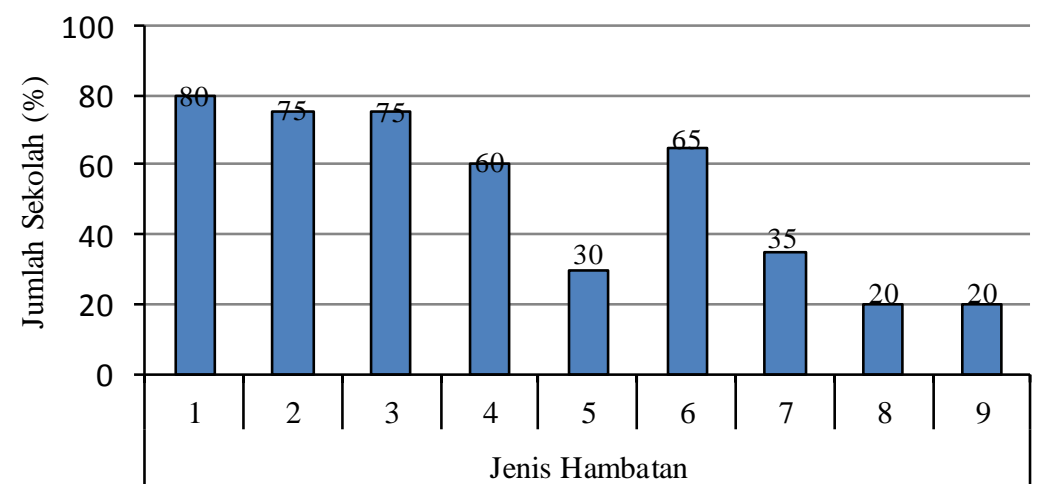

Gambar 1. Grafik persentase jumlah sekolah dan jenis hambatan yang dihadapi dalam menyelenggarakan praktikum fisika

Keterangan :

1: Ketersediaan prasarana/alat praktikum yang terbatas, 2: Peralatan yang ada banyak yang telah rusak, 3: Jam mengajar guru padat, 4: Praktikum membutuhkan waktu lama, 5: Pengelolaan laboratorium belum baik/maksimal, 6: Tidak ada laboran yang membantu meyiapkan alat, 7: Tidak ada Lembar Kerja Siswa/penuntun praktikum, 8: Guru mengalami kesulitan dalam merancang praktikum, 9: Motivasi siswa dalam praktikum rendah

\section{SIMPULAN DAN SARAN}

Berdasarkan hasil penelitian dapat disimpulkan, sebagai berikut : 1) Jenis peralatan praktikum fisika yang dimiliki sekolah-sekolah SMA di wilayah miskin di Provinsi Bengkulu adalah berupa kit fisika, alat ukur dasar, dan alat peraga praktikum dengan ketersediaan minim dan kondisi kurang baik. 2) Terdapat 31 judul praktikum yang direncanakan dalam kurikulum sekolah SMA di wilayah miskin propinsi Bengkulu. Keterlaksanaan judul praktikum tersebut untuk kelas $\mathrm{X}$ dan $\mathrm{XI}$ masingmasing berada pada kategori cukup baik, dan kelas XII pada kategori kurang baik. Rerata keterlaksanaan praktikum secara keseluruhan yang meliputi ketiga jenjang kelas berada pada kategori kurang baik. 3) Bentuk hambatan yang paling sering dialami guru di sekolah adalah berupa ketersediaan peralatan praktikum yang terbatas, peralatan yang ada sudah banyak yang rusak, jam mengajar guru yang padat, dan praktikum membutuhkan waktu lama. 


\section{DAFTAR PUSTAKA}

Antara News. (2010). Siswa Miskin di Bengkulu Terima Beasiswa. [Tersedia Online] http:// hileud.com/hileudnews?title $=25.040+$ Siswa $+\mathrm{M}$ is kin+di+

Bengkulu + Terima + Beasiswa\&id $=446752$.

Diakses Tanggal 19/04/2011.

Carsadi. (2011). Penduduk Miskin di Bengkulu. [Tersedia Online] http://hileud.com/penduduk-miskin-dibengkulu-324930-jiwa.html. Diakses Tanggal $19 / 04 / 2011$

Hut, P. (2006). Virtual laboratories. Progress of Theoretical Physics, Vol. 11, No. 3

Manurung, S dan Rustaman, N. (2010). Hands and minds activity dalam pembelajaran fisika kuantum untuk calon guru. Prosiding Seminar Nasional Fisika. Bandung: SPs UPI.

MDGs. (2007). Laporan Pencapaian Millenium Development Goals Indonesia 2007. Badan Perencanaan Pembangunan Nasional. Jakarta.
Putri, D.H, dan Sutarno, M. (2012). Model Kegiatan Laboratorium Berbasis Problem Solving pada Pembelajaran Gelombang Dan Optik untuk Meningkatkan Keterampilan Proses Sains dan Pemahaman Konsep Mahasiswa. Jurnal Exacta, Vol X No 2. Universitas Bengkulu.

Setiawan, A., Hamidah, I dan Suhandi, A (2009). Pengembangan virtual laboratory Fisika modern yang berorientasi keterampilan generik sains. Laporan akhir Penelitian strategis nasional tahun anggaran. Bandung: SPs UPI

Sudibawa, I.P. (2010). Virtual eksperimen: mencegah miskonsepsi dalam pembelajaran sains. Artikel Pendidikan dan Pembelajaran. Singaraja: Undiksha

Wagania, H. (2008). Pengembangan dan penggunaan simulasi pada multimedia interaktif sebagai alternatif dalam melaksanakan praktikum fisika bahasan rangkaian listrik dan dasar elektronika bagi guru-guru fisika SMA di kota Manado. Abdimas, Vol 1 No 2. 